\title{
Supply of Physical Resources in Accommodation Facilities: with Examples from Bulgaria
}

\author{
Elena PETKOVAa1 \\ a Sofia University "St. Kliment Ohridski", no 15, Tsar Osvoboditel Av., Sofia, Bulgaria
}

\begin{abstract}
The purpose of the article is to give guidelines to explore whether organizations of a specific service sector - accommodation facilities - work with local or with foreign suppliers to supply physical resources. Whether these resources would be supplied from near or from far places is mostly related to the realization of sustainable development and in particular to the environmental impacts. However, whether organizations work with local or with foreign suppliers also have an influence on international trade and revitalization of the economy. The present study concerns a specific economic sector - the hotel industry. In this regard, firstly, a classification of the physical resources of accommodation facilities is presented. Next, a performance of a survey is suggested to explore which types of these physical resources and to what extent is supplied from local and from foreign suppliers at accommodation facilities in a certain region or a country. For the purpose of the study, a questionnaire was developed and suggested to be filled by representatives of accommodation facilities. The questionnaire is tested with four accommodation facilities that are located in the capital city of Sofia, Bulgaria. The studied accommodation facilities are different in type, construction, category (stars) and capacity. Due to the small number of objects - only four - each of which represents a different type of an accommodation facility - generalization in conclusions could not be made. Therefore, the results can serve only as examples and for the formation of baseline hypotheses for further studies that should stretch over all types of accommodation facilities and bigger sample of objects in order to be representative for the accommodation sector of a country, in particular - of Bulgaria.
\end{abstract}

Key words: accommodation facilities, suppliers, certificates, physical resources, Bulgaria

\section{Introduction and literature review}

Physical resources and the process of their supply to the service organizations are a topic that is poorly researched in the scientific literature. That is because service sectors need less physical resources than manufacturing. On the other hand, all

\footnotetext{
${ }^{1}$ Corresponding author: Elena PETKOVA, e-mail: epetkova@hotmail.com. Received in February, revised in May, and September, published in October.
} 
economics sectors and activities need physical resources to be performed. Moreover, whether these resources would be supplied from near or from far places is mostly related to the realization of sustainable development and in particular to the environmental impacts. However, whether organizations work with local or with foreign suppliers also have an influence on international trade and revitalization of the economy.

According to scientific literature, key processes of business activities typically include: (1) value creation processes, focused on primary goods or services; (2) support processes, such as purchasing materials and supplies; and (3) general management processes that "coordinate key value creation and support processes to achieve organization goals and objectives" (Collier \& Evans, 2010: 11). The issues about the activities in the hotel sector are discussed in a number of literary sources (Bardi, 2011; Barrows, Powers, and Reynolds, 2012; Kappa, Nitschke, and Schappert, 1997; Kasavana \& Brook, 2011; Lawson, 1995; Lundberg, 1994; Walker, 2001, etc.). These and other sources describe mainly front office operations, housekeeping service, etc. Mainly business processes related to the sale and provision of hotel services are revealed, and it is considered that these are the processes that create value in that sphere of the economy. Meanwhile, in the scientific literature the process of supply/ delivery of physical resources in hotel industry is less widely reviewed and it is not considered as a main (value creation), but is usually referred to as a supporting process. Hotel industry is considered a part of the service sector, with its products being predominantly of non-physical, i.e. of intangible nature, requiring a few physical resources. That is why, it is assumed that the process of supply/ delivery of physical resources in that sphere is supportive and is somehow overlooked, while customer service processes and those of the sale and provision of services, which add value to the customers are being studied in depth.

However, "in reality most operations systems produce a mixture of goods and services. Most goods have some supporting service element (e.g. maintenance facility), called a facilitating service, while many services will have supporting goods (e.g. a management consultancy report), termed a facilitating well" (Porter, 2009: 8). That is why there are still some significant studies of the supply processes in the hotel industry. The results of these studies show that effective policy and successful practices in supply chain management, in tourism as a whole and in the hotel industry in particular, lead to higher service quality and customer satisfaction, (Nassiry, Ghorban, and Nasiri, 2012). Moreover, they help companies to save time and money (Higley, 2004) and to achieve competitive advantage and operational performance (Vencataya, Seebaluck, and Doorga, 2016). 
For this reason, we consider the process of supplying physical resources in hotel industry to be important. Physical resources in the hotel industry determine the conditions under which the hotel staff can perform hotel operations in order to meet the requirements of the hotel customers. The features of physical resources determine the ways of organizing the services for the clients and consequently how efficient the operations related to customer service would be (Petkova, 2013). Successful management of the hotel supply processes leads to a reduction in delivery time and costs, delivery of high-quality physical resources, and a corresponding increase in business profits. The effective maintenance of the physical facilities also depends on the physical resources and the supply processes. To support that statement is the view in the literature that "planned maintenance relies on the ready availability of suitable materials and spares. At the same time because of economic and space limitations, stocks must be kept to a reasonable minimum. An efficient system of stock monitoring and control is essential. This must ensure that spares are replaced as they are used and that demand for additional items (such as in corrective maintenance) is anticipated" (Lawson, 1995: 319).

When we look at the issue of hotel supplies, we need to clarify their scope. In this respect, the following types of physical resources can be differentiated according to the types of items (Petkova, 2013; Petkova, 2015): the surrounding area and the buildings; furnishings (furniture and decor); equipment (appliances and installations); materials and consumables. The building has a long life span; furniture and equipment - medium - and they are used repeatedly in the hotel activities; and the materials and consumables are short-lived, are used once in the business, and then are wholly transformed. All of these physical resources serve the needs of customers or the needs of hotel staff. In a similar way, the authors often divide physical resources of hotel industry into two groups of recycled and non-recycled inventories, whereas "recycled inventories are those items that have relatively limited useful lives but that are used over and over again". These "include linen, uniforms, guest loan items, and some machines and equipment." And "non-recycled inventories are those items that are consumed or used up during the course of routine's operations" and "include cleaning supplies, small equipment items, and guest supplies and amenities" (Kappa, Nitschke, and Shappert, 1997: 109).

A specific issue concerning supplies in the hotel industry is whether to use local products or accordingly to import them. It is often considered that by choosing local suppliers of physical resources in hospitality and tourism companies contribute to sustainable development as transport, which has a strong negative impact on the environment is used less intensely. A number of hotel businesses prefer to use 
suppliers who practice sustainable production and thus produce environmentally friendly products, health products, etc. That is why those companies often require their suppliers to possess some specific certificates of quality of their products.

That policy is also supported by the European Tourism Indicator System, which "is defined as a locally owned and led process for monitoring, managing and enhancing the sustainability of a tourism destination." (EC, 2013: 27). In that system there are 'Section B. Economic Value Indicators' and 'B.5. Tourism Supply Chain Indicators' that includes an indicator 'B.5.1. Percentage of Tourism Enterprises that actively takes steps to source local, sustainable, and fair trade goods and services'. In this respect, the official opinion of the European Commission is that: "connecting tourism businesses with local producers and suppliers of tourism - related goods and services helps multiply the economic impact of tourism in the destination" (EC, 2013: 27). In addition, it is considered that the funds that "expire" from the economy in the form of imports cease to generate further increases in incomes (Vodenska, 2006). That means that when accommodation facilities import products and physical resources, it results in a "leak" of funds from their income that is paid for these imported goods. Alternatively, these funds could be used to buy local products, which would in turn lead to the development of the local economy and, accordingly, to raising the standard of living of the local population. Therefore, the import of goods and services could have a negative impact on the development of the local economy.

Looking from a different viewpoint, however, it might be stated that the use of imported goods could lead to the development of international trade. That is supported by views expressed in the scientific literature (Samuelson \& Nordhaus, 1998; Tribe, 2011) that free international trade is a means of achieving efficiency. It leads each country to specialize in the production of those goods and services that it produces better than others do, and consequently the efficiency and welfare at a global level increases. As stated by Samuelson \& Nordhaus (1998: 673), "trade promotes specialization and specialization increases productivity. Over the long run, increased trade and higher productivity raise living standards for all nations". Therefore, opening up the "economies to the global trading system is the most secure road to prosperity" (Samuelson \& Nordhaus, 1998: 673). That is determined by 'The theory of comparative advantage', that is developed by the economist David Ricardo. According to Tribe (2011:336-337), after Ricardo different countries have different resources and therefore different costs for producing goods and services. "It therefore pays countries not to attempt to be self-sufficient in producing a complete range of goods and services but to specialize in those where its production costs are lowest and their production efficiency highest" (Tribe, 2011: 336-337). Ricardo 
argued (Tribe, 2011: 336-337), "specialization and trade would lead to an increase in total output compared to a position of no specialization and trade". Therefore, "free trade could bring greater economic benefits to those involved than a position of no trade" (Tribe, 2011: 336-337). Many world organizations such as the World Trade Organization promote free trade. The European Union itself is a union among states, which is developed with the aim to liberalize trade, i.e. to promote and realize benefits from free trade among its Member States.

These contradictory views make us adopt a balanced approach in which it is useful for the companies of a country to import goods but not to realize too many imports. Thus, on the one hand, companies would use largely the products of local suppliers, which will contribute to the sustainable local development. On the other hand, foreign suppliers will be used to a lesser extent, in order to benefit from the specialization of the country and free international trade. In that study, we explore to what extent accommodation facilities in Sofia, Bulgaria use domestic or foreign products.

A broader study exploring some similar issues was carried out with a significantly higher number of tourist companies in Sofia in 2015, namely 138 tourist enterprises, of which 51\% are accommodation facilities, and the other - catering and entertainment facilities, transport companies, etc. V. Marinov and team as a part of the implementation of the ETIS system in Sofia Municipality conducted the study. The results of the study show that a significant part of the surveyed enterprises in Sofia Municipality are supplying local goods and services other than food and beverages: $51 \%$ of enterprises report a share of local goods and services over $25 \%$ (including $26 \%$ - over $50 \%$ ), but $33 \%$ report a share of local goods and services up to $10 \%$. The share of the companies that used over $25 \%$ of local goods and services in accommodation sector is greater - $62 \%$. Similar, but slightly more favorable, are the results for the supply of food and beverages. Most of the surveyed enterprises use a significant share of local food and beverages: $58 \%$ of enterprises report a share of local foods and beverages over $25 \%$ (including $27 \%$ - over $50 \%$ ). That share is again higher for the accommodation facilities (63\%), (Marinov, 2017). Although a significantly smaller number of accommodation facilities are included in the present study, the results are similar (though probably not representative): these businesses rely heavily on local supplies and, to a lesser extent; they use foreign supplies in their business activities. While the study of Marinov et al. (2017) include a large number of tourist enterprises, the study in this article regards only accommodation facilities as types of organizations with specific characteristics, which use specific types of physical resources to a certain extent. Therefore, it is explored which particular types of physical resources are supplied by local and which - by foreign suppliers. 
In this background, the purpose of the article is to give guidelines to explore whether organizations of a specific service sector - accommodation facilities - work with local or with foreign suppliers to supply physical resources. The present study concerns a specific economic sector - the hotel industry. In this regard, firstly, a classification of the physical resources of accommodation facilities is presented. Next, a performance of a survey is suggested to explore which types of these physical resources and to what extent is supplied from local and from foreign suppliers at accommodation facilities in a certain region or a country.

The study tries to test the following hypotheses.

H1: Various types of accommodation use different types of physical resources to varying degrees.

H2. Largely, for the supply of these resources, they use local suppliers - from the administrative district - and, to a lesser extent - ones from other administrative regions of the country, as well as some from abroad.

H2-1: Accommodation units' facilities are encouraged to use local suppliers to short the delivery times and the opportunities for timely response when insufficiency of physical resources occurs.

H2-2: Accommodation units' representatives require physical resources of high quality and sometimes - certificates from their suppliers.

H3: The physical resources and the process of their delivery are important for the sample accommodation facilities.

\section{Methods and the research design}

For the aims of the present study, a model of physical resources in the accommodation facilities is developed and showed in Figure 1. The physical resources are divided into the following groups according to their purpose and duration: building materials, furnishings, equipment, bed linen and towels, and materials and consumables. Building materials are used for the construction and maintenance of the building of the accommodation facility, which is necessary for the performance of the hotel activities and is characterized by a long-term time of operation. Furnishings and equipment are characterized by average time of the operation and are used repeatedly in the activities of the accommodation facility. Equipment replaces human labor in completely or in part, while furnishings create comfort for the people and contributes to the decoration of the premises. Textile articles such as bed linen and towels are important in the hotel industry. They are used repeatedly in the service process. They also have an average duration of use. 
They are generally included in the previous group, but due to the large amount and specific maintenance required for them in the hotel industry, we have included them in a separate group. Materials and consumables are characterized by a short duration of use, they are used only once in the hotel business, after which they are completely transformed and lose their value. The individual types of physical resources can serve the needs of customers during their stay in the accommodation facilities or might be used by staff when carrying out their work at hotel premises. They can be delivered either from more remote regions - from abroad - or from closer ones - from the country where accommodation facilities are situated. In the latest case, it can be included both the nearby suppliers (from the administrative district) and from those located farther away, but again in a short distance away (from other districts of the country, excluding the administrative district).

\begin{tabular}{|c|c|c|c|c|}
\hline \multicolumn{5}{|c|}{ Physical resources in hotel industry } \\
\hline & & Furnishing & \multirow{2}{*}{$\overline{\text { Equipment }}$} & \multirow[b]{2}{*}{$\begin{array}{l}\text { Materials and } \\
\text { consumables }\end{array}$} \\
\hline $\begin{array}{c}\text { Construction } \\
\text { materials } \\
\end{array}$ & $\begin{array}{l}\text { Bed linen and } \\
\text { towels }\end{array}$ & Furnishing & & \\
\hline & & & & \\
\hline \multicolumn{3}{|c|}{ For customers } & \multicolumn{2}{|c|}{ For the operation of staff } \\
\hline \multicolumn{3}{|c|}{ 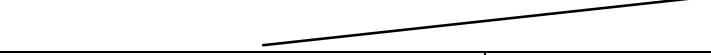 } & & \\
\hline \multicolumn{2}{|c|}{$\begin{array}{c}\text { From the administrative } \\
\text { district }\end{array}$} & \multicolumn{2}{|c|}{ From other districts of the country } & From abroad \\
\hline
\end{tabular}

Figure 1. Physical resources of the accommodation facilities. Source: author

The physical resources of the "Food and Beverage" department in the hotel industry are different in terms of their characteristics and intended use. In the present study, they are analyzed based on the model presented in Figure 2. When food and beverage services are provided in accommodation facilities, utensils for preparing meals and drinks by staff and vessels for serving those items by personnel and consuming meals and drinks by clients are used. Sometimes a large number of textile items, such as tablecloths and cloth napkins are necessary. All of the resource types listed here so far is of average duration of use and they are used repeatedly in the activities of the accommodation facility. In addition, materials and consumables provided by the Food and Beverage department (such as paper napkins, soaps, detergents, etc.) that have a short life span, are used once in the hotel activities, and then completely lose their values are needed. Both staff during their work and customers for their needs use them. Additionally, the hotel industry uses, prepares and provides a significant amount of products for preparing both meals and drinks, as well as purchases finished goods: meals, semi-prepared meals and drinks. They again 
have a short usage period and they are used once in the activities. These products can be included in the previous group, but because it is the main production provided to customers by the department, they are grouped as a separate group. All physical resources of the department again can be supplied from closer or remoter geographic areas, i.e. from the administrative district, from other districts of the country or from abroad.

\begin{tabular}{|c|c|c|c|c|}
\hline \multicolumn{5}{|c|}{ Physical resources of Food and Beverage Department of accommodation facilities } \\
\hline \begin{tabular}{|c|} 
Utensils \\
For preparing \\
meals and drinks \\
\end{tabular} & \begin{tabular}{c}
\multicolumn{2}{c}{ Vessels } \\
For serving and \\
consuming meals and \\
drinks \\
\end{tabular} & $\begin{array}{l}\text { Tablecloths and } \\
\text { cloth napkins }\end{array}$ & \multicolumn{2}{|c|}{$\begin{array}{c}\text { Materials and } \\
\text { consymables } \\
\text { For customers and } \\
\text { staff } \\
\end{array}$} \\
\hline \multicolumn{2}{|c|}{ Foodstuffs: } & \multicolumn{3}{|c|}{ Finished goods: } \\
\hline For making meals & For making drinks & Meals and semi-prep & d meals & Drinks \\
\hline From the administr & \begin{tabular}{|l|l|} 
tive district & From o \\
\end{tabular} & er districts of the cou & & abroad \\
\hline
\end{tabular}

Figure 2. Physical resources of Food and Beverage Department of the accommodation facilities. Source: author

Sources of supply of physical resources in hotel industry, which are used by the companies, can be indicative of both: policy aimed at using local products and suppliers in order to achieve sustainable development in the region and the intensity of international trade as a source for specialization, and respectively to increase the welfare of the world's population.

The method of the study we suggest is a survey to be conducted through a structured questionnaire. The survey aims to answer the following research questions. Whether accommodation facilities work with local or with foreign suppliers to supply physical resources, which would influence the environment and lead to the realization of benefits from international trade? Which particular types of physical resources of accommodation facilities as specific organizations are supplied to a greater or to a lesser extent from local or from foreign suppliers? Are there any requirements for certificates of the physical resources supplied to the accommodation facilities, which can also have an impact on working with suppliers from particular geographical areas? 
For the purpose of the study, a questionnaire was developed and suggested to be filled by representatives of accommodation facilities. The questionnaire is tested with four accommodation facilities that are located in the capital city of Sofia, Bulgaria. The studied accommodation facilities are different in type, construction, category (stars) and capacity. Due to the small number of objects - only four - each of which represents a different type of an accommodation facility - generalization in conclusions could not be made. Therefore, the results can serve only as examples and for the formation of baseline hypotheses for further studies that should stretch over all types of accommodation facilities and bigger sample of objects in order to be representative for the accommodation sector of a country, in particular - of Bulgaria.

The questionnaire contains questions about their supply policy and to what extent they use products of local suppliers. In this regard, the respondents would have the opportunity to indicate for each physical item the extent to which they work with suppliers from the administrative district, from other regions of the country and from abroad. In the beginning of the questionnaire, common characteristics of the accommodation facility should be stated, such as type, category, capacity (size). The following questions concern the supplies and deliveries of physical resources received during the previous year. In this sense, the respondents had to point out what share of the cost of supplies is incurred on the various types of physical items (building materials; furnishings and equipment; textile articles and materials and consumables) for the needs of the clients and for the work of the staff. It should have to be pointed separately for the section "accommodation" and separately for the "food and beverage" section of the accommodation facility. In the following questions, respondents would have to point out the origin of all of these types of physical resources, i.e. where they were supplied from - from the administrative district, from other regions of the country or from abroad. The questionnaire also provides the opportunity to respondents for expressing their attitude towards working with local suppliers. Finally, the respondents would be asked to indicate whether the goods that were delivered to their premises were subject to requirements for possession of some kind of quality certificate in the last year. Almost all questions of the survey are closed, which allows the questionnaire to be completed more quickly by the respondents and the results to be processes more easily.

A test/ sample survey was conducted during the period of 2015-2016. The method of sending the questionnaires through e-mail to the representatives of the accommodation facilities was chosen because we thought that it would take less time for the respondents to complete them. Although a large number of e-mails have been sent, replies and completed questionnaires were received back only by four sites. On 
the one hand, this probably does not guarantee representativeness of the sample. On the other hand, however, the sites whose representatives filled the questionnaire are significantly diverse by category, type and capacity. That makes the process of the analysis of the results meaningful, as the answers could be evaluated according to the characteristics of the object and thus a better understanding of the supply policy and the types of physical resources in the hotel industry to be gained. The four objects are of a different type and they are of some of the most widespread types of accommodation facilities in the city. Therefore, we could explore whether different types of accommodation facilities use different types of physical resources to a varying degree and to what extent they work with local and with foreign suppliers. Moreover, any opinion is important to us. In addition, the respondents provided a large amount of information. However, the results of the present study cannot be used to make conclusions for accommodation sector as a whole, but only serve as an example for performing further studies with bigger sample and for forming baseline hypotheses to explore the important issues of international trade, local welfare and sustainable development. In further studies, it also might be worthwhile other methods of research, such as personal meetings with representatives of accommodation facilities for filling the questionnaires, as well as possibly measures, such as shortening and simplifying the questionnaire to be considered.

\section{Results of study - Examples from Sofia, Bulgaria}

The four accommodation facilities surveyed are of a different kind. One of them is a hotel, the other is a hostel (or as it is called by its owner - a youth hotel targeted for cultural tourists), and the rest - a guesthouse and guest apartments. The studied sites are of different categories: low (1 star) - the hostel and the guest house; middle (3 stars) - the guest apartments; and high (4 stars) - the hotel. The accommodation facilities, which are of different types and categories, are also characterized by a varied capacity, represented by number of rooms and number of beds. The high-class hotel is of the highest capacity with a number of rooms ranging from 61 to 70 , and the number of beds - between 11 and 120, and the guesthouse is of the smallest capacity (1-9 rooms and 11-20 beds). The hostel has more beds (41-50) than guest apartments (31-40), though the number of rooms of both objects is approximately the same (11-20). That is probably due to the specificities of the two types of accommodation facilities related to the market segments of tourists they are targeting, as well as to their construction. Apartments seeking to attract families and business travelers for longer stays have a number of common rooms, such as a kitchen, a living room, a corridor, etc. and 2-3 sleeping rooms with a small number of 
beds $-2,3$, 4, etc. Meanwhile the hostels are targeting at price-sensitive youths looking for entertainments in the region and are characterized by the availability of a large number of beds in every bedroom (Table 1).

Table 1. Characteristics of the accommodation facilities whose representatives participate in the questionnaire survey

\begin{tabular}{|l|l|l|l|}
\hline Type of property & Category/ stars & Number of rooms & Number of beds \\
\hline Guest apartments & 3 & $(11-20)$ & $(31-40)$ \\
\hline Hostel & 1 & $(11-20)$ & $(41-50)$ \\
\hline Hotel & 4 & $(61-70)$ & $(111-120)$ \\
\hline Guest house & 1 & $(1-9)$ & $(11-20)$ \\
\hline
\end{tabular}

Table 2. Shares of the cost of supplying goods for the operation of the accommodation facility in the previous year incurred to the types of physical resources

\begin{tabular}{|l|l|l|l|l|}
\hline Type of property/\% & Apartments & Youth hostel & Hotel & $\begin{array}{l}\text { Guest } \\
\text { house }\end{array}$ \\
\hline Building materials for repairs and renovations & 10 & 14 & 10 & 45 \\
\hline $\begin{array}{l}\text { Furnishings (furniture and decoration) used by } \\
\text { customers }\end{array}$ & 5 & 9 & 0 & 10 \\
\hline $\begin{array}{l}\text { Furnishings (furniture and decoration) used for the } \\
\text { operation of staff }\end{array}$ & 10 & 9 & 0 & 10 \\
\hline $\begin{array}{l}\text { Equipment (appliances and installations) for the needs } \\
\text { of customers during stay }\end{array}$ & 5 & 14 & 0 & 10 \\
\hline $\begin{array}{l}\text { Equipment (appliances and installations) for the needs } \\
\text { of personnel at work }\end{array}$ & 5 & 9 & 10 & 10 \\
\hline Bed linen and towels & 20 & 9 & 10 & 5 \\
\hline Materials and consumables for the needs of customers & 25 & 18 & 30 & 5 \\
\hline $\begin{array}{l}\text { Materials and consumables necessary for the work of } \\
\text { personnel }\end{array}$ & 20 & 18 & 40 & 5 \\
\hline Total (\%) & 100 & 100 & 100 & 100 \\
\hline
\end{tabular}

In three of the accommodation facilities - the apartments, the hostel and the hotel the share of the costs of materials and consumables was the largest (45\% for the apartments, 36\% for the youth hostel and 70\% for the hotel) of the shares of all types of physical resources. Considerably large is the share of these costs at the hotel, which is a place of a full service accommodation, and cleaning and refilling with hotel cosmetics there is performed daily. In the guest apartments, significant costs were also incurred for the purchase of bed linen and towels (20\%). The hotel distinguishes itself from the other three types of accommodation facilities in that: unlike the other three types of sites, the hotel did not incur costs for replacing the furniture used by the customers and for the work of the staff, as well as the equipment that is used by customers. That is probably due to the fact that the hotel offers high quality equipment and furnishings that do not require replacement as often as those of the other accommodation facilities. It can also be assumed that the guest house was renovated and refurbished in the previous year with the largest and most significant 
share of the purchase of building materials - 45\% - followed by the share of furnishings and equipment costs - by $20 \%$ - and the least from the total costs is the share of the costs for materials, consumables and bed linen - a total of $15 \%$. A fewer renovations and refurbishments were probably performed in the other accommodation facilities - the youth hostel (14\% of the costs) and the hotel and the apartments (by $10 \%$ of their total costs are incurred for that activity). The furniture is replaced in the guest house $(20 \%$ of the costs), the youth hostel $(18 \%)$ and the apartments (15\%); the equipment used by customers - also in these three types of accommodation facilities, with a share of costs of between $5 \%$ and $14 \%$; and the equipment used by staff was somewhat refurbished in all four accommodation facilities (with shares of costs 10\%, 9\% and 5\%) (Table 2).

Table 3. Approximate share of the costs for supplying goods - food and beverages for the operation of the accommodation facilities in the last year, by types of physical resources

\begin{tabular}{|l|l|l|}
\hline Type of property & Hotel & Guest house \\
\hline Utensils for preparing meals and drinks & 5 & 50 \\
\hline Vessels for serving and consuming meals and drinks & 5 & 0 \\
\hline Tablecloths and cloth napkins & 15 & 0 \\
\hline $\begin{array}{l}\text { Supplied materials and consumables (paper napkins, soap, detergents, etc.) used by } \\
\text { clients and by staff }\end{array}$ & 15 & 50 \\
\hline Food products for preparing meals & 35 & 0 \\
\hline Products for preparing drinks & 10 & 0 \\
\hline Ready and semi-prepared meals & 0 & 0 \\
\hline Ready drinks & 15 & 0 \\
\hline Total & $100 \%$ & $100 \%$ \\
\hline
\end{tabular}

Only the representatives of two of the accommodation facilities indicated that they are offering food and beverage service - the hotel and the guest house. At the guest house, half of the costs were spent on the purchase of utensils for preparing meals and drinks (50\%) and the rest (50\%) - for the supplied materials and consumables to be used by customers and staff. The fact that no vessels for serving, food products and ready meals and drinks were purchased, probably shows that the house provides only a fully equipped kitchen, where guests serve themselves by purchasing the food and beverages they consume. This self-service organization is typical for a guest house accommodation. Most funds of the hotel were spent on products for preparing meals (35\%) and drinks (25\% in total of which $15 \%$ for ready-made beverages and $10 \%$ for products for drinks). Less are the costs for supplying tablecloths and cloth napkins, as well as supplies and consumables to be used by customers and staff (15\%), and the least are those for utensils for preparing and vessels for serving meals and drinks (5\%). Probably the utensils and vessels of the hotel are of a high quality and do not need to be replaced too often, and restaurants have a good workload and turnover, which is why fresh products are usually ordered. That is typical and 
indicative of efficiency of a Food and Beverage department in high-category hotels (Table 3).

Table 4. Value of supplies for the accommodation facilities - from the administrative district, from the country and from abroad - in the previous year.

\begin{tabular}{|c|c|c|c|c|c|c|c|c|}
\hline \multirow{2}{*}{$\begin{array}{l}\text { Type of property } \\
\text { Region }\end{array}$} & \multirow{2}{*}{$\begin{array}{l}\text { Apart } \\
\text { ments } \\
\text { From } \\
\text { the } \\
\text { adminis } \\
\text { trative } \\
\text { district }\end{array}$} & \multirow{2}{*}{$\begin{array}{l}\begin{array}{l}\text { Youth } \\
\text { hostel }\end{array} \\
\text { From } \\
\text { the } \\
\text { adminis } \\
\text { trative } \\
\text { district }\end{array}$} & \multicolumn{3}{|l|}{ Hotel } & \multicolumn{3}{|c|}{ Guest house } \\
\hline & & & $\begin{array}{l}\text { From } \\
\text { the } \\
\text { adminis } \\
\text { trative } \\
\text { district }\end{array}$ & $\begin{array}{l}\text { From the } \\
\text { country } \\
\text { (without } \\
\text { the } \\
\text { administ } \\
\text { rative } \\
\text { district) }\end{array}$ & $\begin{array}{l}\text { We } \\
\text { did } \\
\text { not } \\
\text { have } \\
\text { such }\end{array}$ & $\begin{array}{l}\text { From } \\
\text { the } \\
\text { admin } \\
\text { istrati } \\
\text { ve } \\
\text { dist- } \\
\text { rict }\end{array}$ & $\begin{array}{l}\text { From the } \\
\text { country } \\
\text { (without } \\
\text { the } \\
\text { administ } \\
\text { rative } \\
\text { district) }\end{array}$ & $\begin{array}{l}\text { From } \\
\text { abro- } \\
\text { ad }\end{array}$ \\
\hline $\begin{array}{l}\text { Building materials for repairs } \\
\text { and renovations }\end{array}$ & 100 & 100 & 100 & & & 100 & & \\
\hline $\begin{array}{l}\text { Furnishings (furniture and } \\
\text { decoration) used by customers }\end{array}$ & 100 & 100 & & & 100 & & & 100 \\
\hline $\begin{array}{l}\text { Furnishings (furniture and } \\
\text { decoration) used for the } \\
\text { operation of staff }\end{array}$ & 100 & 100 & & & 100 & & 10 & 90 \\
\hline $\begin{array}{l}\text { Equipment (appliances and } \\
\text { installations) for the needs of } \\
\text { customers during stay }\end{array}$ & 100 & 100 & & & 100 & & & 100 \\
\hline $\begin{array}{l}\text { Equipment (appliances and } \\
\text { installations) for the needs of } \\
\text { personnel at work }\end{array}$ & 100 & 100 & 100 & & & & 10 & 90 \\
\hline Bed linen and towels & 100 & 100 & & 100 & & 10 & & 90 \\
\hline Hotel cosmetics for guests & 100 & 100 & & 100 & & & & \\
\hline Detergents and cleaners & 100 & 100 & 100 & & & & 60 & 40 \\
\hline
\end{tabular}

Most often, the materials, consumables, and goods of accommodation facilities has been purchased from suppliers located nearby - within the administrative district. All supplies of materials, consumables, furnishings and equipment to two of the accommodation facilities - the apartments and the youth hostel - were purchased only by local suppliers - organizations within the administrative district. The hotel has worked with suppliers from the administrative district (purchasing building materials, equipment to be used by the staff, detergents and cleaners) and from other regions of the country (for bed linen and towels, and hotel cosmetics for customers), but not with ones from abroad, (i.e. suppliers usually located at a longer distance). Only the guest house has used suppliers from all three geographical areas. All construction materials for repairs and renovations (100\%), as well as a small part of bed linen and towels $(10 \%)$ were delivered from the administrative district. More than half of chemical and cleaning products (60\%), as well as small portions of furniture for staff and equipment to be used by personnel (10\%) were delivered from the other administrative districts of Bulgaria. Significant is the import of the guest 
house from abroad, as all the furniture used by the clients and all the equipment that serves their needs, as well as almost all the furnishings necessary for the work of the staff (90\%) and the equipment for the personnel (90\%), and a relatively large proportion of chemical and cleaning products (40\%) were imported from abroad. For all types of accommodation facilities, building materials for repairs and renovation are purchased only from the administrative district, the furnishings and equipment assigned to be used by customers and by the staff, as well as bed linen and towels, detergents and cleaners are supplied by organizations and persons from all three areas - the administrative district, other regions of the country and abroad, and hotel cosmetics for customers are supplied by suppliers from the country - located in the administrative district and in other regions of the state but not from abroad (Table 4).

A question about the physical resources of the Food and Drinks Department has been answered only by the representatives of the hotel, with all supplies being purchased by local suppliers within the administrative district (including utensils for preparing and vessels for serving and consuming meals and drinks, table cloths and napkins, materials and consumables used by clients and staff, products for preparing meals and drinks and ready drinks).

Table 5. Opinions about the use of local supplies by representatives of the types of the accommodation facilities

\begin{tabular}{|l|l|}
\hline Property & Opinion \\
\hline Apartments & $\begin{array}{l}\text { "We do not need to supply from another administrative district or from abroad. There } \\
\text { is a good choice in Sofia." }\end{array}$ \\
\hline Hotel & $\begin{array}{l}\text { "The hotel policy is related to the use of local suppliers in terms of shorter delivery } \\
\text { times and timely response when the necessary quantities are exhausted." }\end{array}$ \\
\hline Guest house & "Positive." \\
\hline
\end{tabular}

In a free text, the representatives of the accommodation facilities had the opportunity to express their attitude towards the use of local supplies. Three of them have taken advantage of this opportunity: the apartments, the hotel and the guest house. Their representatives have a positive attitude towards the policy of using local services and goods. As a reason, they indicate the good choice of physical resources from local suppliers available in the region, the shorter delivery times, and the ability to react promptly when the required inventory quantities are exhausted (Table 5).

In the last question, respondents had the opportunity to indicate whether they required the goods delivered to them in the past year to hold any certificates. The representatives of the apartments and the guest house have noted that they did not have such requirements for any kind of goods. The hotel monitors the expiration date for physical resources that are less durable (such as products for preparing meals and drinks, ready-made beverages, materials and consumables used by customers and by staff, and building materials for repairs and renovations). In addition, a quality 
certificate is required for the material used to make bed linen and towels. In the youth hostel, anti-allergic and eco-friendly products, as well as recycled goods and materials are used (including building materials, furnishings and equipment, materials and consumables for customers and staff, textiles and products for the preparation of beverages) (Table 6).

Table 6. Requirements of accommodation facilities for quality and types of certificates of the goods that were delivered there in the last year

\begin{tabular}{|c|c|c|c|c|}
\hline $\begin{array}{l}\text { Types of physical resources: name of } \\
\text { certificates, signs on the packaging, } \\
\text { etc. }\end{array}$ & $\begin{array}{l}\text { Apart- } \\
\text { ments }\end{array}$ & Youth hostel & Hotel & $\begin{array}{l}\text { Guest } \\
\text { house }\end{array}$ \\
\hline $\begin{array}{l}\text { Building materials for repairs and } \\
\text { renovations }\end{array}$ & No & Recycled & Expiry date & No \\
\hline $\begin{array}{lll}\text { Furnishings } \quad \text { (furniture } & \text { and } \\
\text { decoration) used by customers } & \\
\end{array}$ & No & Anti-allergic & No & No \\
\hline $\begin{array}{l}\text { Furnishings (furniture and } \\
\text { decoration) used for the operation of } \\
\text { staff }\end{array}$ & No & Anti-allergic & No & No \\
\hline $\begin{array}{l}\text { Equipment (appliances } \\
\text { installations) for the needs of } \\
\text { customers during stay }\end{array}$ & No & $\begin{array}{l}\text { Anti-allergic } \\
\text { Eco-friendly }\end{array}$ & No & No \\
\hline $\begin{array}{l}\text { Equipment (appliances } \\
\text { installations) for the needs of } \\
\text { personnel at work }\end{array}$ & No & $\begin{array}{l}\text { Anti-allergic } \\
\text { Eco-friendly }\end{array}$ & No & No \\
\hline Bed linen and towels & No & $\begin{array}{l}\text { Anti-allergic } \\
\text { Eco-friendly }\end{array}$ & $\begin{array}{l}\text { Certificate of quality of } \\
\text { material }\end{array}$ & No \\
\hline $\begin{array}{l}\text { Materials and consumables for the } \\
\text { needs of customers }\end{array}$ & No & $\begin{array}{l}\text { Anti-allergic } \\
\text { Eco-friendly }\end{array}$ & Expiry date and origin & No \\
\hline $\begin{array}{l}\text { Materials and consumables necessary } \\
\text { for the work of personnel }\end{array}$ & No & $\begin{array}{l}\text { Anti-allergic } \\
\text { Eco-friendly }\end{array}$ & Expiry date and origin & No \\
\hline $\begin{array}{l}\begin{array}{l}\text { Utensils for preparing meals and } \\
\text { drinks }\end{array} \\
\end{array}$ & No & No & No & No \\
\hline $\begin{array}{l}\text { Vessels for serving and consuming } \\
\text { meals and drinks }\end{array}$ & No & No & No & No \\
\hline Tablecloths and cloth napkins & No & No & No & No \\
\hline $\begin{array}{l}\text { Supplied materials and consumables } \\
\text { (paper napkins, soap, detergents, etc.) } \\
\text { used by clients and by staff }\end{array}$ & No & $\begin{array}{l}\text { Anti-allergic } \\
\text { Eco-friendly }\end{array}$ & Expiry date and origin & No \\
\hline Food products for preparing meals & No & No & $\begin{array}{l}\text { Expiry date, date of } \\
\text { manufacture, origin, } \\
\text { means of transport }\end{array}$ & No \\
\hline Products for preparing drinks & No & Eco-friendly & Expiry date and origin & No \\
\hline Ready and semi-prepared meals & No & No & No & No \\
\hline Ready drinks & No & No & Expiry date and origin & No \\
\hline
\end{tabular}

\section{Discussion}

As a result of the test study it was found that different types of accommodation facilities often prefer to work with local suppliers. They realize that it leads to less transport costs by reducing delivery times and therefore better responding to customer needs for availability of tangible products at the place of accommodation at any time. Accommodation representatives are positively positioned to use local 
supplies. We can assume that if these results are proven in further, representative studies, on the one hand, it would be indicative of sustainable usage of physical resources in the hotel industry, environmental protection, increased revenues of local businesses and, accordingly, well-being of local residents. On the other hand, goods, which are delivered by suppliers from other regions of the country (without the administrative district) and from abroad are used by the surveyed accommodation facilities too, though, to a lesser extent? If it turns out to be valid for the hotel industry of the country as a whole, that is favorable for the development of national and international trade and, accordingly, could improve the welfare of people around the world, as well as the global economic development. To sum up, if the hypothesis that the accommodation facilities use to a larger extent local suppliers, but to a certain extent also foreign ones is proven, probably hotel industry contributes both to the sustainable economic development in the country and to the realization of benefits of international trade and revitalizing the economy. In this way, benefits of both sustainable local development and international trade are being realized.

\section{Conclusions}

International trade is of significance for the specialization of countries, hence for the revitalization of economies and economic development. However, economic development should not have negative impacts on the environment, i.e. it should be sustainable. That is why, in our opinion, organizations of every economic sector, including hotel industry should work to a large extent with local suppliers of physical resources, but to a certain degree - also with foreign ones. Consequently, we suggest a thorough study of the accommodation facilities in Bulgaria to be performed concerning to what extent these organizations work with local and with foreign suppliers. In the present study, we suggested guidelines for performing such research as follows. Firstly, a classification of physical resources of accommodation facilities was offered. Next, a questionnaire was developed in order to explore to what degree at different types of accommodation facilities are supplied various types of physical resources and from which areas - the administrative district, other districts of the country or abroad. In this regard, it should also be explored whether the organizations require physical resources supplied to have any certificates of quality.

The questionnaire has been tested as four accommodation facilities of different types have been surveyed as a test study to serve as an example for future research. As the four accommodation facilities are of different types, it is supposed that they would use the kinds of physical resources to a varying degree. The main results of the study of the physical resources and the supply policy of different types of 
accommodation facilities in Bulgaria, and specifically in Sofia can serve as baseline hypotheses for further research studies that should be representative at a national level for Bulgaria. They are outlined as follows. In most of the surveyed accommodation facilities, the largest share was of the costs incurred for materials and consumables - used by customers plus by staff. Most often, sample accommodation facilities has purchased materials, consumables, and goods from local suppliers from the administrative district. To a certain extent, the objects also work with suppliers from other administrative districts of the country, as well as from abroad. Respondents have a positive opinion on the use of local supplies, believing that thus they reduce delivery times and react quickly to the exhaustion of the inventories quantities. Some of the sample accommodation facilities require the supplied products to be of a high quality and environmentally friendly. If the hypotheses are proven in further research studies, it could be concluded that specialization is achieved and consequently some benefits of the international trade are realized, leading in turn to economic development. Meantime, this development is sustainable and environment is protected. The performance of such representative studies is important for the economies of the countries, for the enhancement of the welfare of population and simultaneously natural resources would be sustained.

As a focus of further research, we recommend scientists to address also the question of how local supplies in hotel industry lead to specific economic, environmental and social impacts and benefits for the region and whether it is sometimes more effective to use imported goods in order to revive international trade and the world economy. In this respect, specific quantitative indicators should be used to measure the economic, environmental and social effects of supply of physical resources to hotel industry at a regional, national, European and global level. It would also be appropriate to study a larger number of accommodation facilities so that the results are representative. As a result of the present study, attention to the supply of physical resources in the hotel sector was paid. It was pointed out what types of physical resources were probably delivered to various kinds of accommodation facilities largely in view of their specifics of functioning and meeting the needs of customers. The roles of local and foreign supplies were reviewed.

\section{References}

1. Bardi, J., 2011. Hotel front office management, Fifth edition, John Wiley \& Sons, Inc., Hoboken, New Jersey.

2. Barrows, C., Powers, T., Reynolds, D., 2012. Introduction to management in the hospitality industry, Tenth edition, John Wiley \& Sons, Inc., Hoboken, New Jersey.

3. Collier, D., Evans, J., 2010. Operations management, Second edition, Cengage Learning. 
4. European Tourism Indicator System (ETIS) Toolkit for Sustainable Destinations. EC. DG Enterprise and Industry. February 2013.

5. Higley, J., 2004. Supply-chain policies help hoteliers save time, money, in Hotel and Motel Management, 219(3), p. 26 - 27.

6. Kappa, M., Nitschke, A., Shappert, P., 1997. Housekeeping management, Second edition, Educational Institute: American Hotel \& Lodging Association. ISBN: 0-86612-156-0.

7. Kasavana, M., Brooks, R., 2001. Managing front office operations, Sixth edition, Educational Institute: American Hotel \& Lodging Association.

8. Lawson, F., 1995. Hotels and resorts: Planning, design and refurbishment, Architectural Press. Butterworth Heinemann Publishers: London.

9. Lundberg, D., 1994. The hotel and restaurant business, Sixth edition, John Wiley \& Sons, Inc., Hoboken, New Jersey.

10. Marinov, V., 2017. The contribution of the tourist enterprises to the sustainable tourism development, on the example of Sofia, Annual of Sofia University "St. Kliment Ohridski" - Faculty of Geology and Geography. Book 2 - Geography. Volume 109. University Press "St. Kliment Ohridski". Sofia, p. 233-249 - in Bulgarian.

11. Nassiry, M., Ghorban ZS, Nasiri A., 2012. Supply chain management and service quality in Malaysian hotel industry, European Journal of Business and Management. Vol. 4(12), p 119-126.

12. Petkova, E., 2013. Hotel Operations: Main highlights of the hotel technology, management and economy, Auto Spectrum - in Bulgarian.

13. Petkova, E., 2015. Models in the hotel industry, First edition, University Press "St. Kliment Ohridski". Sofia - in Bulgarian.

14. Porter, A., 2009. Operations management, Albert Porter and Ventus Publishing Aps. Books Boon. www.bookboon.com.

15. Samuelson, P., Nordhaus, W., 1998. Economics, Sixteenth edition, McGraw-Hill, Boston.

16. Tribe, J. 2011. The economics of recreation, leisure and tourism, Fourth edition, Elsevier Ltd.

17. Vencataya, L., Seebaluck AK, Doorga D., 2016. Assessing the impact of supply chain management on competitive advantage and operational performance: a case of four star hotels of Mauritius, International Review of Management and Marketing. Vol. 6(4), p. 61-69.

18. Vodenska, M., 2006. Tourism and Society, MBBU Publishing House, Sofia - in Bulgarian,

19. Walker, J., 2001. Introduction to hospitality, Upperside River, Prentice Hall.

20. Snyder, G., 1990. Practice of the Wild. North Point Press, San Francisco.

(C) 2019 by the authors. Submitted for possible open access publication under the terms and conditions of the Creative Commons Attribution-Non Commercial-No Derivatives (CC BY NC ND) 4.0 International License. (https://creativecommons.org/licenses/by-nc-nd/4.0/). 